\title{
RESEARCH ON THE IMPACT OF PERCEIVED SERVICE FAIRNESS AND PRICE FAIRNESS ON THE COMPLAINING BEHAVIOUR OF RESTAURANT CUSTOMERS
}

DOI: 10.17261/Pressacademia.2020.1188

JBEF- V.9-ISS.1-2020(1)-p.1-11

Cenk Murat Kocoglu ${ }^{1}$, Merve Yildirim Kalem ${ }^{2}$

${ }^{1}$ University of Karabuk, Safranbolu Faculty of Tourism, Department for Tourism Management, Karabuk, Turkey. cenk-murat@hotmail.com, ORCID: 0000-0002-9888-6051

${ }^{2}$ University of Karabuk, Safranbolu Faculty of Tourism, Department for Tourism Management, Karabuk, Turkey. mrvyldrm21@gmail.com, ORCID: 0000-0002-0101-539X

Date Accepted: March 18, 2020

To cite this document

Koçoğlu, C.M., Kalem, M.Y. (2020). Research on the impact of perceived service fairness and price fairness on the complaining behaviour of restaurant customers. Journal of Business, Economics and Finance (JBEF), V.9(1), p. 1-11.

Permemant link to this document: $\mathrm{http} / / /$ doi.org/10.17261/Pressacademia.2020.1188

Copyright: Published by PressAcademia and limited licenced re-use rights only.

\begin{abstract}
Purpose -The aim of research is to determine perceptions of service fairness and price fairness of restaurant customers; to measure how perceptions of service fairness and price fairness affect their complaining behaviour.

Methodology - A structured questionnaire technique was used as data collection method. A total of 410 useable questionnaires were collected from customers of 40 restaurants in Karadeniz Ereğli. The data collected was analysed using the factor analysis, regression and correlation analysis.

Findings- There is moderate positive correlation between perceived service fairness and perceived price fairness in restaurant customers in Karadeniz Ereğli. A moderate negative correlation between perceived service fairness and complaining behavior was found. A low negative correlation between perceived price fairness and complaining behavior was found.

Conclusion- The study provides practical implications that provides restaurants decreasing their customers' complaining behaviour and new insight on the relationship between perceived service fairness and perceived price fairness of restaurant customers.
\end{abstract}

Keywords: Perceived service fairness, perceived price fairness, complaining behaviour, restaurant customers, tourism marketing JEL Codes: L83, Z31, Z33 


\section{INTRODUCTION}

Customers seek fairness in terms of benefits and services provided to them. As with any profit organizations, the main objective of restaurants is to meet customers' expectations, providing customers a good service and making profit. Pricing is a challenging but a significant managerial decision since the price of a product or service affects customers' behaviour significantly (Chung and Petrick, 2015: 907). Since restaurants are operating in tourism industry and tourism industry which is one of the most important industries in terms of human mobility; restaurants should give importance to service providing and pricing. Customer satisfaction or dissatisfaction from the products and services offered in restaurants has various impacts on complaining behaviour. In fierce competition environment, for their standing, restaurants should focus on the impact of customer perceived price fairness and service fairness on complaining behaviour.

In related literature, there are studies about the effects of perceived service fairness and perceived price fairness on loyalty, on customer satisfaction and consumer behaviour (Çilesiz and Selçuk, 2018; Malc et al., 2016; Xia et al., 2004). This study is considered to be important in terms of presenting the relationship between the variables and the effects of variables on each other effects. In the related literature, there is no study that attempts to discuss the relationship among perceived price fairness and perceived service fairness. In this context, this research is thought to be fulfil this deficiency in the literature.

The aim of the research, in the scale of Karadeniz Ereğli, is to determine perceptions of service fairness and price fairness of restaurants customers; to measure how perceptions of service fairness and price fairness affect their complaining behaviour. In this study, data were collected from 410 restaurant customers in Karadeniz Ereğli and necessary analyses were made. In the direction of the results obtained, this research attempts to contribute both to related literature and to the restaurants in Karadeniz Ereğli about determining the impacts of perceived service fairness and perceived price fairness on complaining behaviour.

\section{LITERATURE REVIEW}

In this part of the study, the concepts of perceived service fairness, perceived price fairness, complaining behavior and the relationship between these variables are explained.

\subsection{Perceived Service Fairness}

In service evaluation, service fairness has emerged as a significant concept. Seiders and Berry (1998) defines service fairness as "perception of the customer's degree of fairness related to the service providing of a service company. Customer's perceived service fairness is important in terms of increasing reputation and reliability of the enterprises operating in service industry and consequently gaining competitive advantage (Herbig and Milewicz, 1993).

Characteristics of services such as variability, intangibility and inseparability increase the sensitivity of consumers to the service fairness. Lack of trial before purchasing a service, increases this sensitivity for the potential customers. Therefore, it would be difficult for potential customers to evaluate the service before purchasing (Berry et al., 1994).

On the other hand, the concept of perceived service fairness plays an important role in defining service quality and customer satisfaction (Hui et al. 2007). In this context, the rupture or continuity of the relationship between customers and tourism enterprises is closely related to the perception of fairness. Therefore, to establish and maintain long-term relationships with customers in a business, fair treatment of customers is essential (Berry 1999). Customers value whether the results are fair when evaluating the success of service improvement activities (Hoffman and Kelly, 2000).

In the related literature, equity theory and justice theory were usually mentioned in researchs. Equity theory was developed by Adams (Adams, 1963; Adams, 1965) and has been studied in the researchs in the fields of sociology, psychology and organizational behavior (Oliver and DeSarbo, 1988). Most of the researchers in the field of justice have based their studies on Adams's equity theory (1963) (Goodwin and Ross, 1990; McCollough, 2000). Equity theory consists of three components: distributive fairness, procedural fairness, and interactional fairness (Hoffman and Bateson, 2006). According to this theory, the satisfaction levels of the customers and their future attitudes towards enterprises are depending on whether they feel that they are treated fairly or unfairly (McColl-Kennedy and Sparks, 2003).

The FAIRSERV service fairness model proposed by Carr (2007) is developed as multidimensional model that attempts to measure service fairness and explains consumer reactions to the services (Carr, 2007). Customers evaluate services by comparing services with standards of fairness and the treatment of other customers. In this evaluation, factors such as arrival time of meals and presentation can be counted. As a result, they evaluate service as fair or not. In their study about restaurants, Namkung and Jang (2009) stated that interactional fairness has a direct impact on behavioral intentions. 


\subsection{Perceived Price Fairness}

Price is "the total of all the values that customers leave to get the benefit of having or using a product or service" (Kotler et al., 2005). Price is one of the most important factors affecting the behavior of both enterprises and customers (Hanaysha, 2016). In related literature, there are several definitions made on perceived price fairness. Xia et al. (2004) defined price fairness as a customer's assessment between a price of a product or service and the price of a comparative other party is reasonable, acceptable, or justifiable (Xia et al., 2004). Frey and Pommerehne (1993) claimed that customers assess fairness as "fair price". Moreover, Padula and Busacca (2005) defined perceved price fairness as the consumer's subjective judgment as to whether the actual price is "fair" as a result of his/her assessment of the economic value provided by the exchange relationship with the supplier. Campbell (1999) stated that price fairness is a significant factor to consider, as it affects brand image and perceived price may result in negative word of mouth communication and customers may switch to competitors.

When the customer perceive a price as unfair, he/she may withdraw from a purchase, make negative word of mouth or act in a variety of ways to harm the business (Xia et al., 2004). In a study, researchers examined perceived price fairness towards dynamic pricing system newly introduced in the maritime transport industry and impacts of perceived price fairness on consumers' perception on a company or brand reputation. This study was conducted on the customers of IDO A.Ş. a fast sea transporattion enterprise in Turkey. For this purpose, data were collected from 126 participants, who got ticket from IDO and traveled in intercity lines. Results show that there are relationships between consumer trust, consumers' percieved price fairness, consumer satistaction, consumer attitudes towards the enterprise and brand reputation (Nacar et al., 2012). In literature, many studies have focused on the determinants that affect the perceived price fairness of customers when enterprises increase the price of a product or service (Kukar-Kinney et al., 2007; Kahneman et al., 1986a; Kahneman et al., 1986b; Bechwati et al., 2005; Bolton et al., 2003; Campbell, 2007).

In the studies, it was stated that perceived price fairness or unfairness is a psychological factor which has a significant impact on the reactions of consumers to prices. Consumers do not want to pay a price when they perceive unfair and they react to this unfairness in a variety of ways, such as less purchases (Campbell, 1999).

\subsection{Complaining Behaviour}

A complaint refers to feedback of customers from their dissatisfaction (Barlow and Moller, 2008). Acquiring a new customer is more costly in terms of time, energy, and resources (Weinstein, 2002). For this reason, businesses should ensure the continued satisfaction of existing customers. Therefore, it is important for businesses to evaluate complaints in order to resolve unsuccessful services and to maintain relationships with existing customers.

In the act of complaining, customers may employ different methods. In some cases, customers do not take any action which means withdraw from a purchase and switch to a competitor and in some cases they report their complaint in different ways (Day and Landon, 1977). Customers may complain to the manager (Hirschman, 1970), share complaints with other people in consumer associations, media, intermediary organizations (travel agencies, tour operators, etc.) or on the Internet (holidaycheck, şikayetimvar, etc.) (Kılıç and Ok, 2012). In a study, it was found that the number of complainant customers did not complain to the company manager but shared their complaints with their family and friends was more than the number of those who submitted their complaint to the company manager (Barlow and Moller, 2008).

There are many studies in the literature explaining customers complaining behaviour. Studies explaining customers complaining behaviour began in the 1970s and Hirschman (1970) conducted the first research on customers complaining behavior. In literature, there are studies that attempts to explain; how businesses handle customer complaints, organizational factors affecting customer's tendency to complain to an organization, evaluation of customer complaining behaviours in online shopping and customer complaining management (Gökdeniz et al., 2012; Yılmaz et al., 2016; Alabay, 2012). About the behaviours of consumers who are not satisfied about a product or a service, Hirschman (1970) states that some of the customers who felt that they did not benefit from the goods and services they received, claimed that enterprises had to correct their mistakes. On the other hand, some other customers have decided not purchase from that company again.

\section{DATA AND METHODOLOGY}

The aim of this study is to determine the impacts of perceived service fairness and perceived price fairness on complaining behaviour in restaurants in Karadeniz Ereğli. For this purpose, a quantitative research design was selected and data were collected through structured questionnaire.

For service fairness variable; a cross-sectional scale with multiple items is used which is adopted from Kwortnik and Han (2010). For price fairness variable; a scale created in the light of the information adopted from previous studies by 
Srikanjanarak et al. (2009) is used. For the complaining behavior variable; questions developed by Xia et al. (2004) on complaining behavior were adopted.

In the preparation of questions, previous studies in related literature were utilized (Kwortnik and Han, 2010; Srikanjanarak et al., 2009; Xia et al., 2004; Çilesiz and Selçuk, 2018). Five point Likert scale starting from 1 (strongly disagree) to 5 (strongly agree) was used. To determine the content validity of the questionary form, 3 academic staff were interviewed and the expressions that might pose a challenge in the meanings of questions were corrected.

Before the main survey was conducted, a pilot study was conducted on 40 restaurant customers and the questionnarie was finalized accordingly. The purpose was to be able to foresee the possible problems related to the scale used and the variables in the questionnaire (Yüksel and Yüksel, 2004). The questionnaire consists of three dimensions which are perceived service fairness, perceived price fairness and complaining behavior.

\section{1. Hypothesis Development and Research Model}

Researches (Lam and Tang, 2003; Kim et al., 2010; Blodgett et al., 1993; Su and Hsu, 2013) take part in literature explainig that perceived service fairness has a negative impact on complaining behavior. Similarly, Blodgett et al. (1994) stated that complaining behavior and negative word of mouth communication do not occur a lot in cases where perceived service fairness is high.

Su and Hsu (2013) conducted a study on Chinese natural heritage tourism. They examined relationships among consumption emotions, satisfaction, service fairness and behavioral intentions. They stated that service fairness is an antecedent of consumption emotions (positive and negative) that, it affects behavioral intentions. Thus, the following hypothesis was formulated:

\section{$\mathbf{H}_{1}$ : Perceived service fairness affects complaining behaviour negatively.}

Since price evaluations are based on comparison with the service offered by other enterprises, percived price fairness occurs with price comparisons (Xia and Monroe, 2010). In the related literature, in the majority of perceived price fairness studies, it is found out that "reference price" affects consumer price perceptions (Xia et al., 2004; Maxwell, 2002; Bechwati et al., 2005; Matzler et al., 2006). In previous researches, it was stated that perceived price fairness is an important factor on complaining behavior (Hirschman, 1970; Campbell, 1999; Huppertz et al., 1978; Xia et al., 2004; Namkung and Jang, 2010; Malc et al., 2016). Ferguson and Ellen (2014) examined impacts of procedural and distributive fairness, the main components of perceived fairness, on price fairness. Results of their study demonstrate that procedural fairness and distributive fairness have positive impacts on price fairness. The above researches led to following hypothesis:

$\mathbf{H}_{2}$ : Perceived price fairness affects complaining behaviour negatively.

According to Bolton et al. (2003), fairness is judging an outcome and the process of achieving an outcome as reasonable, acceptable or fair. It is proved with the studies in literature that there is a relationship between perceived service fairness and perceived price fairness. Srikanjanarak et al. claimed that a reliable measure of price fairness perception, provides a beter understanding of about customers perception on price fairness. The specific knowledge leads managers to design an appropriate price strategy which fits their customer's desires and needs while maintaing a long-term relationship with them. Bolton et al. Examined the determinants that affect the perceived price fairness of customers when enterprises increase the price of a product or service. Hassan et al. (2013) attempted to determine the impact of service quality, service fairness and price fairness perception on customer loyalty and customer satisfaction in the mobile telecom industry of Pakistan. Results of their study show that price fairness perception, service quality and service fairness have validity and reliability for measuring customer satisfaction and loyalty (Hassan et al., 2013). Furthermore, a positive relationship between service fairness, service quality and price fairness perception is obtained. In the context of these studies, the following hypothesis was formulated:

$\mathbf{H}_{3}$ : There is a positive relationship between perceived service fairness and perceived price fairness.

The aim of developing a research model is to demonstrate the linkage of relationship between variables. According to the research model, perceived service fairness affects complaining behaviour negatively. Perceived price fairness affects complaining behaviour negatively. There is a positive relationship between perceived service fairness and perceived price fairness. 
Figure 1: Research Model

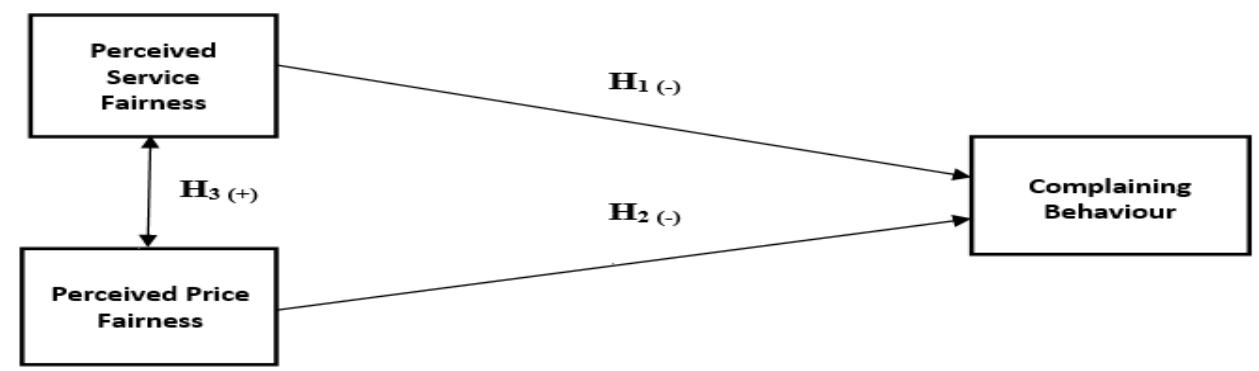

\subsection{Population and Sample of the Research}

The research population consists of restaurant customers in Karadeniz Ereğli. Karadeniz Ereğli has remarkable values with regard to art history, archeology, history and tourism disciplines (Oğuzbalaban and Akın, 2017). When the artifacts and existing tourism opportunities of Karadeniz Ereğli are properly handled within the scope of tourism, the existing tourism potential will increase. In addition, the fact that a similar study was not carried out in this destination was effecting the selection of Karadeniz Ereğli as the population. The questionnaires were conducted in February 2019 for restaurant customers in Karadeniz Ereğli. In the study, convenience sampling method a specific type of non-probability sampling method was used as the sampling method. According to Yüksel and Yüksel (2004), since there are many variables that affect the sample, the researcher should reach the size where he/ she can obtain the appropriate data rather than calculating the sample. Sekaran (2003) suggests that sample size of 384 for $95 \%$ confidence intervals is sufficent in case of population size about one million and above. Sample study constitutes 410 participants reached in February 2019. To achieve the objective of this research, questionnaires were distributed to 425 restaurant customers but 15 questionnaires were incorrectly completed and rejected. Therefore, a total of 410 useable questionnaires were obtained.

\section{FINDINGS AND DISCUSSIONS}

\subsection{Descriptive Statistics}

Acoording to the frequency analysis which was run out for determining demographic characteristics, $40,5 \%$ were male (166) and $59,5 \%$ were female (244). The findings indicate that $36,3 \%(149)$ of participants were in the $27-35$ age range and $31,5 \%$ (129) were in the $18-26$ age range. The minority $4,4 \%$ (18) were between the ages of $54-62.51,7 \%$ (212) of participants were married and $48,3 \%$ (198) were single. Results demonstrate that the majority of participants $54,1 \%(222)$ have bachelor degree, $17,6 \%(72)$ were postgraduate and the minority $2,7 \%(11)$ were primary school graduates. Approximately half of participants have $48,5 \%$ (199) $1500-3500$ TL monthly income.

Table 1: Demographic Characteristics of Study Sample

\begin{tabular}{|c|c|c|}
\hline Demographic Characteristics & $\mathrm{n}$ & $\%$ \\
\hline \multicolumn{3}{|l|}{ Gender } \\
\hline Female & 244 & 59,5 \\
\hline Male & 166 & 40,5 \\
\hline Total & 410 & 100 \\
\hline \multicolumn{3}{|l|}{ Age } \\
\hline 18-26 age & 129 & 31,5 \\
\hline $27-35$ age & 149 & 36,3 \\
\hline 36-44 age & 72 & 17,6 \\
\hline 45-53 age & 42 & 10,2 \\
\hline 54-62 age & 18 & 4,4 \\
\hline Total & 410 & 100 \\
\hline \multicolumn{3}{|l|}{ Marital Status } \\
\hline Single & 198 & 48,3 \\
\hline Married & 212 & 51,7 \\
\hline Total & 410 & 100 \\
\hline
\end{tabular}




\begin{tabular}{|c|c|c|}
\hline \multicolumn{3}{|c|}{ Education } \\
\hline Primary Education & 11 & 2,7 \\
\hline Secondary & 51 & 12,4 \\
\hline Associate degree & 54 & 13,2 \\
\hline Bachelor degree & 222 & 54,1 \\
\hline Postgraduate degree & 72 & 17,6 \\
\hline Total & 410 & 100 \\
\hline \multicolumn{3}{|c|}{ Monthly Income } \\
\hline Less than $1500 \mathrm{TL}$ & 34 & 8,3 \\
\hline 1500 TL-2500 TL & 96 & 23,4 \\
\hline $2501 \mathrm{TL}-3500 \mathrm{TL}$ & 103 & 25,1 \\
\hline 3501 TL- 4500 TL & 84 & 20,5 \\
\hline More than $4501 \mathrm{TL}$ & 93 & 22,7 \\
\hline Total & 410 & 100 \\
\hline
\end{tabular}

Acoording to the frequency analysis which was run out for determining demographic characteristics, 40,5\% were male (166) and $59,5 \%$ were female (244). The findings indicate that $36,3 \%$ (149) of participants were in the $27-35$ age range and $31,5 \%$ (129) were in the $18-26$ age range. The minority $4,4 \%$ (18) were between the ages of $54-62.51,7 \%$ (212) of participants were married and $48,3 \%$ (198) were single. Results demonstrate that the majority of participants $54,1 \%(222)$ have bachelor degree, $17,6 \%(72)$ were postgraduate and the minority $2,7 \%(11)$ were primary school graduates. Approximately half of participants have $48,5 \%$ (199) 1500-3500 TL monthly income.

\subsection{Explanatory Factor Analysis of Variables}

Explanatory factor analysis was made for determining dimensional structures of the variables perceived service fairness, perceived price fairness and complaining behaviour and for examinnig reliability and validity.

Table 2: Factor Analysis of Variables and Means

\begin{tabular}{|c|c|c|c|}
\hline Factors & Factor Loading & Variance (\%) & C.Alfa $(\alpha)$ \\
\hline \multicolumn{2}{|l|}{ Perceived Service Fairness $\bar{x}: 3,77$} & \multirow{6}{*}{40,74} & \multirow{6}{*}{873} \\
\hline The restaurant provided me with what I asked. & 847 & & \\
\hline I was treated respectfully in this restaurant. & ,798 & & \\
\hline The restaurant served me correctly. & ,780 & & \\
\hline Restaurant staff treated me flexibly according to my needs. & ,765 & & \\
\hline The restaurant has fully met my needs. & ,751 & & \\
\hline \multicolumn{2}{|l|}{ Perceived Price Fairness $\bar{x}: 3,09$} & \multirow{4}{*}{30,19} & \multirow{4}{*}{,843 } \\
\hline $\begin{array}{l}\text { Generally, this restaurant offers well priced compared to } \\
\text { other restaurants. }\end{array}$ & 868 & & \\
\hline $\begin{array}{l}\text { The prices charged by this restaurant for food and beverages } \\
\text { are reasonable. }\end{array}$ & 865 & & \\
\hline $\begin{array}{l}\text { This restaurant offers the best possible price that meets my } \\
\text { needs. }\end{array}$ & ,803 & & \\
\hline \multicolumn{4}{|c|}{$\begin{array}{l}\text { Total Variance: 70,94, Deductive Method: Principal Component Analysis, Spinning Method: Kaiser Normalization and } \\
\text { Varimax, Number of iterations: } 3 \\
\text { KMO Conformity Criterion: } 0,783 \text { Barlett's test of sphericity x²: } 1652,813 \text { p: } 0,000\end{array}$} \\
\hline Factor & Factor Loading & Variance (\%) & C.Alfa $(\alpha)$ \\
\hline \multicolumn{2}{|l|}{ Complaining Behaviour $\bar{x}: 2,40$} & \multirow{3}{*}{69,10} & \multirow{3}{*}{,886 } \\
\hline $\begin{array}{l}\text { I would complain to the restaurant manager about this } \\
\text { restaurant. }\end{array}$ & ,906 & & \\
\hline $\begin{array}{l}\text { I would complain to the restaurant staff about this } \\
\text { restaurant. }\end{array}$ & 897 & & \\
\hline
\end{tabular}




\begin{tabular}{|c|c|c|}
\hline $\begin{array}{l}\text { I would ask for an explanation for the prices at this } \\
\text { restaurant. }\end{array}$ & 874 & \\
\hline $\begin{array}{l}\text { I would give negative comments about this restaurant to } \\
\text { others }\end{array}$ & ,750 & \\
\hline I would warn people not to go to this restaurant. & ,709 & \\
\hline \multicolumn{3}{|c|}{$\begin{array}{l}\text { Cronbach Alfa: ,886 Total Variance: } 69,10 \text {, Deductive Method: Principal Component Analysis, Spinning Method: Kaise } \\
\text { Normalization } \\
\text { KMO Conformity Criterion: } 0,766 \text { Barlett's test of sphericity x²: } 1622,145 \text { p: } 0,000\end{array}$} \\
\hline
\end{tabular}

According to Kaiser Normalization in exploratory factor analysis, factors with eigenvalue greater than 1,0 were considered and it was determined that the scale consisted of 3 factors. The total variance percentage is 70,94 for perceived service fairness and perceived price fairness. The total variance percentage for complaining behaviour is 69,10 . According to Scherer et al. (1988), the percentage should be more than $50 \%$ for the validity of the analysis. Therefore, this analysis is valid as these rates are higher than $50 \%$. In the explanatory factor analysis, common variance (communality) values and the values of the scale statements should not be less than 0,4 (Field, 2000). In this factor analysis, all values were not higher than 0,4. The question of perceived service fairness dimension which is "The amount I paid in this restaurant is reasonable for the service I received" is withdrawn because it is overlaped. The question of perceived price fairness dimension "This restaurant provides a variety of pricing plans" is withdrawn because it's factor loading value is less than 0,4 .

As a result of factor analysis, first factor includes 5 statements about perceived service fairness, second factor includes 3 statements about perceived price fairness and third factor includes 5 statements about complaining behaviour. The reliability of all variables was examined, the research indicates that the Cronbach Alpha coefficient of perceived service fairness, perceived price fairness and complaining behaviour were respectively; " 0,873 "; " 0,843 " " 0,886 ". According to Nunnally and Bernstein (1994), the reliability of the scale is accepted as good if the coefficient is found equal or greater than 0.70 . Hence, the values are showing reliable measures to be used in this study.

The findings indicate that perceived service fairness has the highest average $(\bar{x}=3.77)$, it is followed by perceived price fairness $(\bar{x}=3.09)$ and complaining behavior $(\bar{x}=2.40)$ respectively.

The distribution is normal because it was determined that the skewness and kurtosis values were between $-1,5$ and $+1,5$ (Tabachnick and Fidell, 2013). Since the data were distributed normally, Pearson Correlation test was run out.

Table 3: Correlation Analysis

\begin{tabular}{|l|c|c|c|}
\hline Dimensions & $\begin{array}{c}\text { PSF (Perceived } \\
\text { Service Fairness) }\end{array}$ & PPF (Perceived Price Fairness) & CB (Complaining Behaviour) \\
\hline Perceived Service Fairness & 1 &, $468^{* *}$ &,$- 436^{* *}$ \\
\hline Perceived Price Fairness &, $468^{* *}$ & 1 &,$- 351^{* *}$ \\
\hline
\end{tabular}

“**p<0.01"

Findings of correlation analysis are demonstrated in Table 3. which demonstrate the relationships among perceived service fairness, perceived price fairness and complaining behaviour. All correlation coefficients between the variables were found positive and significant $(\mathrm{p}<0.01)$.

When Pearson Correlation coefficients are examined, it is found out that there is a moderate positive relationship between perceived service fairness and perceived price fairness $(r=0,468, p<.001)$. Thus, this particular finding support the acceptance of $\mathrm{H}_{3}$ "There is a positive relationship between perceived service fairness and perceived price fairness". Moreover, results reveal that there is a moderate negative relationship between perceived service fairness and complaining behaviour ( $r=-$ $0,436, p<.001)$. Furthermore, there is a weak negative relationship between complaining behaviour and perceived price fairness $(r=-0,351 ; p<0,01)$.

\subsection{Hypotheses Testing}

To test the model given in Table 3, regression analysis was run out for testing the hypotheses $\mathrm{H}_{1}, \mathrm{H}_{2}, \mathrm{H}_{3}$. 
Table 4: Model of Regression Analysis of Variables

\begin{tabular}{|l|c|c|c|}
\hline \multicolumn{4}{|l|}{ Research Model (Dependent Variable: Complaining Behaviour) } \\
\hline Independent Variables & Beta & $\mathbf{t}$ & $\mathbf{P}$ \\
\hline Perceived Service Fairness &, 348 & 7,016 &, 000 \\
\hline Perceived Price Fairness &, 188 & 3,781 &, 000 \\
\hline R=,467; R $\mathrm{R}^{2}=, 218 ;$ Adjusted $\mathrm{R}^{2}=, 214 ; \quad \mathrm{F}=56,610 ; \quad \mathrm{p}=0.000$
\end{tabular}

Multiple linear regression analysis was run out to test the impact of perceived service fairness and perceived price fairness on complaining behaviour. Results in Table 4 show the model of regression analysis of variables. It is found out that perceived service fairness has a negative significant effect on complaining behaviour $(\beta=0,348 ; p=0,000)$. Thus, this finding support the acceptance of $\mathrm{H}_{1}$ "perceived service fairness affects complaining behaviour negatively". As shown in Table 4 , results show that perceived price fairness has a negative significant effect on the complaint behavior $(\beta=0,188 ; p=0,000)$. Therefore, $H_{2}$ "perceived price fairness affects complaining behaviour negatively" is accepted. Moreover, it was found that the most effective variable on complaining behavior was perceived service fairness.

In addition, since two different variables were included in the model as independent variables, it was tested for multicollinearity. The values of $\mathrm{VIF}=\mathbf{1 , 2 8 1}$ and Tolerance $=\mathbf{0 , 7 8 1}$ indicate that there is no multiple correlation and autocorrelation between the variables (Field, 2000).

\section{CONCLUSION}

The aim of this study is to explain the impacts of perceived service fairness and perceived price fairness on complaining behaviour in restaurants. Results of the study show that perceived service fairness affects complaining behaviour negatively. Similarly, perceived price fairness affects complaining behaviour negatively. In addition, there is a positive relationship between perceived service fairness and perceived price fairness.

Results demonstrate that perceived service fairness has the highest average, it is followed by perceived price fairness and complaining behavior respectively. This result indicates that restaurant customers give importance to service fairness. To be treated respectfully by restaurant staff and to be served correctly are important for them. Secondly, results show that restaurant customers care about reasonable prices of food and beverages, and they compare this prices with other restaurants.

When Pearson Correlation coefficients are examined, it is found out that there is a moderate positive relationship between perceived service fairness and perceived price fairness. Moreover, findings indicate that there is a moderate negative relationship between perceived service fairness and complaining behaviour. There is a weak negative relationship between perceived price fairness and complaining behaviour.

Indeed, the researches about this subject support these research results (Lam and Tang, 2003; Kim et al., 2010; Blodgett et al., 1993; Su and Hsu, 2013; Hirschman, 1970; Campbell, 1999; Huppertz et al., 1978; Xia et al., 2004; Namkung and Jang, 2010; Malc et al., 2016). Huppertz et al. (1978) claimed that when consumers perceive inequity, they leave the shop and complain about price or service.

Multiple regression analysis was conducted to test the effects of perceived service fairness and perceived price fairness on complaining behavior. Results demonstrate that, perceived service fairness has a negative significant effect on complaining behaviour. Moreover, it was found that the most effective variable on complaining behavior was perceived service fairness.

In the related literature it has been claimed that perceived service fairness has a negative effect on complaining behavior (Lam and Tang, 2003; Kim et al., 2010; Blodgett et al., 1993; Su and Hsu, 2013). Hirschman, 1970; Campbell, 1999; Huppertz et al., 1978; Xia et al., 2004; Namkung and Jang, 2010; Malc et al., 2016 in their price fairness researchs, they stated that perceived price fairness was an important factor on complaining behavior.

Based on the results and conclusion of the study, the following recommendations can be made:

Customers perceive the service more fairly when restaurants pay attention to treat their customers respectfully, provide the service correctly, they treat their customers flexibly according to their needs. Thus, complaining behaviour will decrease 
accordingly. In this context; restaurants should treat their customers with respect, provide their services correctly, act flexibly towards customers' needs and fully meet their needs.

If they offer a more favorable price than competing restaurants, set reasonable food and beverage prices and offer the best possible price while meeting the needs of customers, the perception of price fairness will increase and complaining behaviour will decrease. With these improvements, restaurants will increase the perception of price fairness and cause a positive impact on the perception of service fairness.

This study focuses on the impact of perceived service and price fairness on complaining behaviour of restaurant customers, especially in restaurants in Karadeniz Ereğli. In this context, the research is limited with the evaluation of the restaurants in the Karadeniz Ereğli and the local customers in these restaurants. It is recommended that future researchs will be carried out at different destinations with the inclusion of foreign customers. It is thought that future studies on this subject will be carried out in different areas of the service industry and contribute to the literature.

\section{REFERENCES}

Adams, J.S. (1963).Toward an Understanding of Inequity. Journal of Abnormal Psychology. 67,422-436. DOI: 10.1037/h0040968

Adams, J.S. (1965).Inequity in social Exchange, in: Berkowitz L. (Ed.), Advances in Experimental Psychology, 2., Academic Press: New York: 267-299.

Alabay, M.N. (2012). Müşteri Şikâyetleri Yönetimi. Uluslararası Yönetim iktisat ve işletme Dergisi. 8(16): 137-157. DOI:10.11122/ijmeb.2014.8.16.320

Barlow, J., Moller, C. (2008). A Complaint is a Gift: Using Customer Feedback as a Strategic Tool. San Francisco, California: Berrett-Koehler Publishers, Inc.

Bechwati, N.N., Sheth, J.N., and Sisodia, R.S. (2005).Consumers' Perceptions of Pricing Unfairness. Advances in Consumer Research. 32, 388389.

Berry, B.B, Parasuraman, and Zeithaml, V.A. (1994).Improving Service Quality in America: Lessons Learned. Academy of Management

Executive. 8(2): 32-52. DOI: 10.5465/AME.1994.9503101072

Berry, L.L. (1999). Discover the Soul of Service: The nine drivers of sustainable business success,1st ed. New York: Free Press.

Blodgett, J.G., Granbois, D.H., and Walters, R.G. (1993).The Effects of perceived justice on complaints' negative word-of-mouth behavior and repatronage intentions. Journal of Retailing. 69(4): 399-428. DOI:10.1016/0022-4359(93)90015-B

Bolton, L.E., Warlop, L., and Alba, J.W. (2003). Consumer Perceptions of Price (Un) Fairness. Journal of Consumer Research, 29 , 474-49. DOI:10.1086/346244

Campbell, M.C. (1999). Perceptions of price unfairness: antecedents and consequences. Journal of Marketing Research. 36(2): $187-199$. DOI:10.1177/002224379903600204

Campbell, M.C. (2007). Says Who?! How the Source of Price Information and Affect Influence Perceived Price (Un) Fairness. Journal of Marketing Research. 44(2): 261- 271. DOI:10.1509/jmkr.44.2.261

Carr, C.L. (2007).The FAIRSERV Model: Consumer Reactions to Services Based on a Multidimensional Evaluation of Service Fairness. Decision Sciences. 38(1): 107-113. DOI: 10.1111/j.1540-5915.2007.00150.x

Chung, J.Y., James P.F. (2015).Measuring Price Fairness: Development of a Multidimensional Scale. Journal of Travel \& Tourism Marketing. 32(7): 907-922. DOI: 10.1080/10548408.2015.1063894

Çilesiz, E., Selçuk, G.N.(2018, June 30). Hizmet Adaleti, Fiyat Adaleti ve Güven Algılarının Müşteri Memnuniyeti Üzerindeki Etkisi: Kış Koridorunda Konaklayan Yabancı Turistler Üzerine Bir Araştırma. Güncel Turizm Araştırmaları Dergisi. 2(1): 42-78. Retrieved from https://dergipark.org.tr/tr/pub/guntad/issue/38048/419803

Day, R.L., Landon, L. E. (1977).Toward a theory of consumer complaining behavior, in: Woodside, A., Steht, J., Bennet, P. (Ed.), Consumer and Industrial Buying Behaviour, North Holland Publishing Company, Amsterdam: 425-437.

Ferguson, J.L., Scholder, E.P., and Bearden, W.O. (2014).Procedural and Distributive Fairness: Determinants of Overall Price Fairness. Journal of Business Ethics. 121(2): 217-231. DOI: 10.1007/s10551-013-1694-2

Field, A.(2000). Discovering Statistics-Using SPSS for Windows. London: SAGE Publication. 
Frey, B.S., Pommerehne, W.W. (1993).On the Fairness of Pricing-An Empirical Survey among the General Population. Journal of Economic Behavior \& Organization. 20(3): 295-307. DOI: 10.1016/0167-2681(93)90027-M

Goodwin, C., Ross, I. (1990).Consumer Evaluations of Responses to Complaints: What's Fair and Why.Journal of Services Marketing, 4(3): 5361. DOI: /10.1108/EUM0000000002575

Gökdeniz, İ., Durukan, T., and Bozacı, İ.(2012, January 31).Müşterinin Firmaya Şikâyet Etme Eğilimini Etkileyen Örgütsel Faktörler Üzerine $\begin{array}{lllllll}\text { Uygulamalı Bir Çalışma.Üçüncü Sektör Sosyal } & \text { Ekonomi. } & \text { 47(2): } & 30-46 . & \text { Retrieved }\end{array}$ https://dergipark.org.tr/tr/pub/aksarayiibd/issue/22552/240996

Hanaysha, J. (2016). Restaurant Location and Price Fairness as Key Determinants of Brand Equity: A Study on Fast Food Restaurant Industry. Business and Economic Research. 6(1): 310-323. DOI:10.5296/ber.v6i1.9352

Hassan, M., Hassan, S., Nawaz, S.M., and Aksel, I. (2013, October).Measuring Customer Satisfaction and Loyalty Through Service Fairness, Service Quality and Price Fairness Perception: An Empirical Study of Pakistan Mobile Telecommunication Sector. Science International (Lahore). 25(4): 895-904. Retrieved from https://www.researchgate.net/publication/320566386

Herbig, P., Milewicz, J.(1993).The relationship of reputation and credibility to brand success. Journal of Consumer Marketing. 10(3): 18-24. DOI: 10.1108/EUM0000000002601

Herrmann, A., Xia, L., Monroe, K. B., and Huber, F. (2007). The influence of price fairness on customer satisfaction: An empirical test in the context of automobile purchases. Journal of Product \& Brand Management, 16(1): 49-58. DOI: 10.1108/10610420710731151

Hirschman, A. O. (1970). Exit, Voice and Loyalty Responses to Decline in Firms, Organizations and States. Cambridge: Harvard University Press.

Hoffman, K. D., Kelley, S.W. (2000). Perceived Justice Needs and Recovery Evaluation: A Contingency Approach. European Journal of Marketing. 34(3/4): 418-430. DOI: 10.1108/03090560010311939

Hoffman, K. D., Bateson, J. E.G. (2006). Services Marketing: Concepts, Strategies and Cases, 3rd Ed.Thomson: South Western.

Hui, M.K., Au, K., and Zhao, X. (2007). Interactional Justice And The Fair Process Effect: The Role Of Outcome Uncertainty. Journal of Experimental Social Psychology. 43(2): 210-220. DOI:10.1016/j.jesp.2006.02.014

Huppertz, J.W., Arenson, S. J., and Evans, R. H. (1978). An Application of Equity Theory to Buyer-Seller Exchange Situations. Journal of Marketing Research. 15(2): 250-260. DOI: 10.2307/3151255

Kahneman, D., Knetsch, J., and Thaler, R. (1986). Fairness and the Assumptions of Economics. The Journal of Business. 59(4): 285-300. DOI: $10.1086 / 296367$

Kılıç, B., Ok, S. (2012, January 6). Otel İşletmelerinde Müşteri Şikâyetleri ve Şikâyetlerin Değerlendirilmesi. Journal of Yasar University, 25(7): 4189-4202. Retrieved from https://dergipark.org.tr/tr/pub/jyasar/issue/19137/203078

Kim, J.H., Chen, J.S. (2010). The Effects of Situational and Personal Characteristic on Consumer Complaint Behavior in Restaurant Services. Journal of Travel \& Tourism Marketing. 27(1): 96-112. DOI: 10.1080/10548400903539773

Kotler, P., Wong, V. Saunders, J., and Armstrong, G. (2005). Principles of Marketing, 4th Ed. Essex: Pearson Education Limited.

Kukar-Kinney, M., Xia, L., and Monroe, K. B. (2007). Consumers' Perceptions of the Fairness of Price-Matching Refund Policies. Journal of Retailing, 83: 325-337. DOI: 10.1016/j.jretai.2007.03.005

Kwortnik, R. J., Han, X. (2010). The Influence of Guest Perceptions of Service Fairness on Lodging Loyalty in China. Cornell Hospitality Quarterly. 52(3): 321-332. DOI: 10.1177/1938965511409005

Lam, T., Tang, V. (2003). Recognizing Customer Complaint Behavior: The Case of Hong Kong Hotel Restaurants. Journal of Travel \& Tourism Marketing. 14(1): 69-86. DOI: 10.1300/J073v14n01 05

Malc, D., Mumel, D., and Pisnik, A. (2016). Exploring price fairness perceptions and their influence on consumer behavior. Journal of Business Research. 69(9): 3693-3697. DOI: 10.1016/j.jbusres.2016.03.031

Matzler, K., Würtele, A., and Renzl, B. (2006). Dimensions of Price Satisfaction: A Study in the Retail Banking Industry. International Journal of Bank Marketing. 24(4): 216-231.DOI: 10.1108/02652320610671324

Maxwell, S.(2002). Rule-Based Price Fairness and Its Effect on Willingness to Purchase. Journal of Economic Psychology, 23(2): 191-212. DOI: $10.1016 / \mathrm{S} 0167-4870(02) 00063-6$

Mccoll-Kennedy, J.R., Sparks, B. A. (2003). Application of Fairness Theory to Service Failures and Service Recovery. Journal of Service Research. 5(3): 251-266. DOI:10.1177/1094670502238918

McCollough, M. A. (2000).The Effect of Perceived Justice and Attributions Regarding Service Failure and Recovery on Post-Recovery Customer Satisfaction and Service Quality Attitudes. Journal of Hospitality and Tourism Research. 24(4): 423-447. DOI: 10.1177/109634800002400402 
Nacar, R., Polat, V., Geçti, F., and Çiçek, M. (2012). Dinamik Fiyatlandırmada Algılanan Fiyat Adaletinin Marka İtibarına Etkisi: ỉDo Örneği. Balıkesir. 17. Ulusal Pazarlama Kongresi. 805-820. DOI: 10.13140/RG.2.1.4641.8004

Namkung, Y., Jang, S. C. (2010). Effects of Perceived Service Fairness on Emotions and Behavioral Intentions in Restaurants. European Journal of Marketing. 44(9/10): 1233-1259. DOI: 10.1108/03090561011062826

Nunnally, J., Bernstein, I. (1994). Psychometric Theory, 3rd Ed.New York: McGraw-Hill.

Oğuzbalaban, G., Akın, G. (2017). Karadeniz Ereğlisi'nin Destinasyon Olarak Yer Aldığı Turlar Üzerine Bir Araştırma. Uluslararası Sosyal Araştırmalar Dergisi. 10(54): 1108-1113. DOI: 10.17719/20175434679

Oliver, R.L., DeSarbo, W. S. (1988). Response determinants in satisfaction judgments. Journal of Consumer Research. 14: 495-507. DOI: $10.1086 / 209131$

Padula, G., Busacca, B. (2005). The Asymmetric Impact of Price-Attribute Performance on Overall Price Evaluation. International Journal of Service Industry Management. 16(1): 28-54. DOI: 10.1108/09564230510587140

Scherer, R.F., Wiebe, F. A., Luther, D. C., and Adams, J. S. (1988). Dimensionality Of Coping: Factor Stability Using The Ways of Coping Questionnaire. Psychological Reports. 62(3): 763-770. DOI: 10.2466/pr0.1988.62.3.763

Seiders, K., Berry, L.L. (1998). Service fairness: what is and why it matters. Academy of Management Executive. 12(2): 8-20. DOI: 10.5465/ame.1998.650513

Sekaran, U. (2003). Research Methods for Business: A Skill-Building Approach, 4th eds. New York: John Wiley High Education Press.

Srikanjanarak, S., Omar, A., and Ramayah, T. (2009, January). The Conceptualisation and Operational Measurement of Price Fairness Perception in Mass Service Context. Asian Academy of Management Journal. 14(2): 79-93. Retrieved from https://www.researchgate.net/publication/44035887

Su, L., Hsu, M.K. (2013). Service Fairness, Consumption Emotions, Satisfaction, and Behavioral Intentions: The Experience of Chinese Heritage Tourists. Journal of Travel Tourism Marketing. 30(8): 786-805. DOI: 10.1080/10548408.2013.835228

Tabachnick, B.G., Fidell, L.S. (2013). Using multivariate statistics, 6th Eds. Boston: MA: Pearson.

Weinstein, A. (2002). Customer retention: A usage segmentation and customer value approach. Journal of Targeting, Measurement \& Analysis for Marketing. 10(3): 259-269. DOI: 10.1057/palgrave.jt.5740051

Xia, L., Monroe, K.B., and Cox, J.L. (2004). The price is unfair! A conceptual framework of price fairness perceptions. Journal of Marketing. 68(4): 1-15. DOI: 10.1509/jmkg.68.4.1.42733

Xia, L., Monroe, K.B., and Cox, J.L. (2010, July 15). Is a good deal always fair? Examining the concepts of transaction value and price fairness. Journal of Economic Psychology,31(6): 884-894. Retrieved from http://isiarticles.com/bundles/Article/pre/pdf/9331.pdf

Yılmaz, V., Arı, E., and Doğan, R. (2016). Online Alışverişte Müşteri Şikâyet Niyetleri ve Davranışlarının Yapısal Eşitlik Modeli ile İncelenmesi. Journal of Yasar University. 11(42): 102-112. DOI:10.19168/jyu.60269

Yüksel, A., Yüksel, F. (2004). Turizmde Bilimsel Araştırma Yöntemleri. Ankara: Turhan Kitapevi. 